УДК 656.222.1

\title{
АНАЛІЗ ТЕХНОЛОГІЇ РОБОТИ ВИСОКОШВИДКІСНОГО ЗАЛІЗНИЧНОГО ТРАНСПОРТУ
}

Канд. техн. наук Г. О. Примаченко, магістрант 3. А. Аскеров

\section{АНАЛИЗ ТЕХНОЛОГИИ РАБОТЫ ВЫСОКОСКОРОСТНОГО ЖЕЛЕЗНОДОРОЖНОГО ТРАНСПОРТА}

Канд. техн. наук А. А. Примаченко, магистрант 3. А. Аскеров

\section{ANALYSIS OF THE TECHNOLOGY WORK HIGH-SPEED RAIL}

Cand. of techn. sciences G. Prymachenko, master student Z. Askerov

Розглянуто вирішення актуальної проблеми впровадження швидкісного пасажирського руху на залізнииях Украӥни з метою підвищення якості послуг, щзо надаються, $i$ ефективності роботи транспортного комплексу. Для иьього наведено приклади розвитку та впровадження швидкісного та високошвидкісного руху на залізницях світу. Визначено сутність, доцільність, необхідність проведення модернізащії та побудови спеціалізованих залізничних ліній в Украӥні.

Ключові слова: високочвидкісна магістраль, реконструкиія, швидкісний рух, залізнична мережа, пасажиропотік, рухомий склад. 
Рассмотрено решение актуальной проблемы внедрения скоростного пассажирского движения на железных дорогах Украины с иелью повышения качества услуг $u$ эффективности работы транспортного комплекса. Для этого приведены примеры развития и внедрения скоростного и высокоскоростного движения на железных дорогах мира. Определена сущность, иелесообразность, необходимость проведения модернизации и построения специализированных железнодорожных линий в Украине.

Ключевые слова: высокоскоростная магистраль, реконструкиия, скоростное движение, железнодорожная сеть, пассажиропоток, подвижной состав.

We conside solving actual problem of introduction high-speed passenger traffic on the railways of Ukraine to improve the quality of services provided and the efficiency of the transport sector. There are examples of the development and implementation of high-speed and high-speed railways in the world. We essenced appropriateness necessity of modernization and construction of special railway lines in Ukraine. It presents the necessary conditions, aimed at implementing the program of implementation of high-speed passenger traffic. Built simulation model of carrying railway station and the nearby ferrying at different speeds with the use of Petri nets. The model allows identify forward the results to reduce the time of passenger trains on selected portions of the motion before the decision to implement the reconstruction of high-speed movement. The use of models will not only improve the quality of services for passengers, but also to ensure the competitiveness of the transport market of Ukraine.

Keywords: high-speed railway, reconstruction, movement speed railway network, passenger, rolling stock.

Вступ. На протязі останніх десятиліть залізничний транспорт суттєво потіснив автомобільний та став партнером авіаційного транспорту у сфері внутрішньодержавних та міжнародних залізничних перевезень. Поїздки швидкісними та високошвидкісними лініями заміняють використання літаків на відстані 500 - 1000 км завдяки очевидним перевагам залізничного транспорту: безпека, комфорт, надійність, можливість для пасажира прибуття майже у центр міста, зменшений негативний вплив на навколишнє середовище за рахунок використання електроенергії.

Підвищення швидкості руху транспортних засобів має велике значення для суспільства. Воно змінює концепцію життя населення. Використання сучасних швидкісних поїздів зробило нормою мати роботу на відстані 100 км від місця проживання, використання часу перебування у вагоні для роботи та самовдосконалення. Швидкість руху транспортних засобів поряд з глобальною інформатизацією $є$ найбільш вагомими показниками нинішнього етапу науковотехнічного прогресу $[1,2]$.

Проблема кардинального підвищення швидкості руху не може бути вирішена без створення спеціалізованих високошвидкісних магістралей (ВШМ) на залізницях України. При цьому слід звернути увагу, що держава отримує багато позитивних змін від реалізації такого проекту. Додаткові фактори розвитку швидкісного i високошвидкісного руху часто не визначають прямої економічної вигоди для держави, однак відіграють важливу соціальну роль.

Аналіз останніх досліджень i публікацій. Технологія роботи високошвидкісного залізничного транспорту досліджується у багатьох роботах закордонних та вітчизняних вчених [3-6]. Досліджувалися перспективи розвитку швидкісного руху у сполученнях Європа Азія на території України [7], наведені основні недоліки та переваги у порівнянні 3 існуючою системою залізничних 
сполучень. Питання розкрито частково оглядом наявних досліджень.

Проводилось дослідження питання реконструкції наявної залізничної мережі 3 метою впровадження високошвидкісного руху [8]. Порівнювалися варіанти будівництва нових ліній для швидкісного залізничного руху та реконструкції існуючих. Також наведені основні недоліки та переваги кожного з варіантів.

Процес організації високошвидкісного руху було докладно розкрито у [9]. Розглянуто основні напрямки реформування та державного регулювання розвитку залізничного транспорту України [10], у тому числі при впровадженні високошвидкісного руху.

Але питання аналізу технології роботи високошвидкісного залізничного транспорту не було повно розглянуто.

Визначення мети та задач дослідження. Мета статті - розкрити питання технології роботи високошвидкісного пасажирського залізничного транспорту в транспортному комплексі України.

Поставлена мета визначила основні задачі дослідження:

- аналіз обсягів та структури пасажирських перевезень у внутрішньому сполученні;

- аналіз вітчизняних і закордонних теоретичних розробок i практичного досвіду технології пасажирських перевезень для визначення ступеня завантаження основних пристроїв залізничних станцій при обслуговуванні пасажиропотоку.

Основна частина дослідження. Позитивними аспектами розвитку високошвидкісного руху є [11]: підвищення ділової активності та мобільності населення, в тому числі розвиток торгівлі, туризму, всієї сфери обслуговування, збільшення транспортної доступності регіонів країни; додаткові можливості залучення великих інвестицій, в тому числі й іноземних, отримання відповідних податкових відрахувань до бюджетів; прискорення науково-технічного прогресу на залізничному транспорті, в транспортному машинобудуванні i транспортному будівництві; підвищення конкурентоспроможності країни на світовому ринку транспортних послуг, а також експортного потенціалу вітчизняної промисловості; створення нових робочих місць, міграція населення в регіони будівництва й експлуатації високошвидкісних ліній; економія паливно-енергетичних i матеріальних ресурсів після початку експлуатації ВШМ; підвищення рівня культури та освіченості жителів регіонів за рахунок підвищення можливості спілкування; зміцнення соціальнотериторіальної цілісності держави, інтеграція регіонів тяжіння.

При визначеній ефективності того чи іншого виду транспорту перш за все враховують витрати часу на поїздку, що напряму залежать від швидкості руху.

Виходячи 3 цього повітряний транспорт слід було б вважати найбільш перспективним видом високошвидкісного транспорту. Однак внаслідок багатогранності умов, в яких виконуються пасажирські перевезення, а також неоднакової собівартості перевезень пасажирів різними видами транспорту такі висновки $\epsilon$ неоднозначними. Незважаючи на те, що швидкісні можливості залізничного транспорту нижчі, ніж у повітряного, при визначених умовах високошвидкісні пасажирські поїзди виявляються більш зручними та рентабельнішими для пасажирів, ніж літаки.

Переваги високошвидкісного руху пасажирських поїздів яскраво проявляються при визначеній дальності перевезень пасажирів. При дальності перевезень до 650-750 км затрати часу для пасажирів при використанні ВШМ будуть меншими, ніж на повітряному транспорті. Перевезення пасажирів на такі відстані слід визнати оптимальними саме залізничним транспортом.

У даний час високошвидкісний залізничний транспорт при організації 
масових перевезень пасажирів впевнено посідає транспортну нішу в діапазоні відстаней 400-800 км, забезпечуючи найменший сумарний час у дорозі, тобто найбільшу загальну швидкість поїздки при найвищих показниках безпеки, комфортабельності та економічності. За даними Міжнародного Союзу Залізниць (MC3), при часі в дорозі по магістральній частині маршруту до 2,5 год більше $75 \%$ пасажиропотоку припадає на ВШМ, при часі 3,5-4,0 год пасажиропотік розподіляється між поїздами і літаками, а при часі понад 4,5 год більш привабливим для пасажирів стають авіаперевезення.

Понятяя «високошвидкісний залізничний транспорт» має відносний характер і може різнитися залежно від країни та історичного періоду застосування. Зокрема, ще на початку XX століття високошвидкісними називали поїзди, що рухалися зі швидкостями понад 160 км/год. В зв'язку 3 подальшим зростанням швидкостей руху поїздів дана планка поступово підвищувалася. На сьогодні ж високошвидкісним наземним транспортом вважається залізничний транспорт, що забезпечує рух швидкісних поїздів зі швидкістю понад 250 км/год. по спеціалізованих лініях, або зі швидкістю більше 200 км/год. по вже існуючим коліям. Але слід брати до уваги, що в залежності від регіону градація швидкостей дещо відрізняється.

\section{Сучасний}

високошвидкісного розвитку залізничного транспорту характеризується тим, що у світовій спільноті стала використовуватись ще одна градація швидкостей. Якщо раніше практично однозначно виділялись поняття «високошвидкісні залізниці», «високошвидкісний поїзд» (в англомовній літературі - high speed railways, high speed train), то тепер все частіше трапляються такі поняття, як надзвичайно або дуже високошвидкісна (в англомовній літературі - extreme high speed, very high speed) залізниця або поїзд.
Відповідно до цього, у зарубіжній залізничній літературі, зокрема і в матеріалах МС3, виник розподіл ліній, призначених для високошвидкісного руху, на три категорії:

- швидкісні - для швидкостей руху 200-250 км/год (звичайні реконструйовані магістральні лініі);

- високошвидкісні - для швидкостей 250-300 км/год (спеціально побудовані високошвидкісні лінії);

- надзвичайно або надвисокошвидкісні - для швидкостей понад 300 км/год (спеціально побудовані надвисокошвидкісні лінії).

Аналогічно стали розділяти і поїзди. Декілька компаній, що випускають рухомий склад для ВШМ, уже створили або близькі до створення надвисокошвидкісних поїздів. Так, компанія Siemens (Німеччина) розробила поїзди-платформи Velaro, призначені для Іспанії та Китаю (конструкційна швидкість 350 км/год.); компанія Alstom (Франція) - поїзд AGV (360 км/год); компанія Sifang (Китай) поїзд Zefiro 380 (380 км/год); компанія Talgo (Іспанія) - поїзд Avril (380 км/год), i компанія Hyundai Rotem (Республіка Корея) - поїзд HEMU-430 (430 км/год).

Для світової, в тому числі і для української залізничної теорії і практики така ситуація викликає необхідність корегування термінології для адекватного розуміння ситуації у світі 3 високошвидкісним рухом і власного стану в цій сфері. Оцінюючи сучасну ситуацію 3 організацією високошвидкісного руху в Україні, очевидно, що наша держава лише розпочинає рух у цьому напрямку.

Для України більш прийнятним буде застосовувати класифікацію швидкостей, зображену на рис. 1.

Для реалізації концепції високошвидкісного руху Україні слід пройти довгий шлях модернізації технологій, створення відповідної інфраструктури, спеціальних ліній, систем сигналізації, централізації та блокування, освоєння спеціального рухомого складу. 


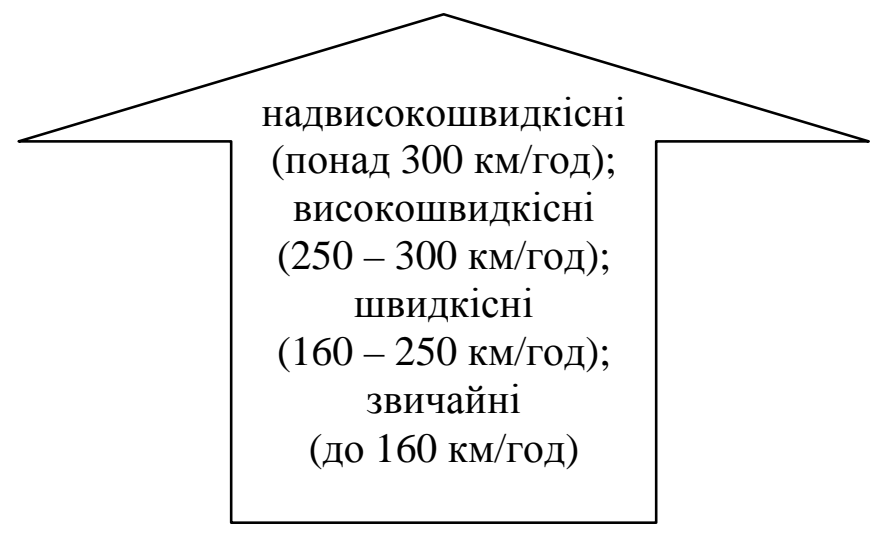

Рис. 1. Схема класифікації залізниць за швидкостями руху

На сьогодні загальна довжина ВШМ у світі становить 17 тис. км, швидкісні поїзди курсують на полігоні сумарною довжиною приблизно 25 тис. км. Із графіка (рис. 2), який було надано в доповіді MC3 на VIII конгресі, видно, що прискорення будівництва залізничних магістралей у світі відбулось після 2004 р., коли почалося втілення в життя будівництва ВШМ у Китаї i Туреччині, розширення будівництва ВШМ в Іспанії і ряді інших країн.

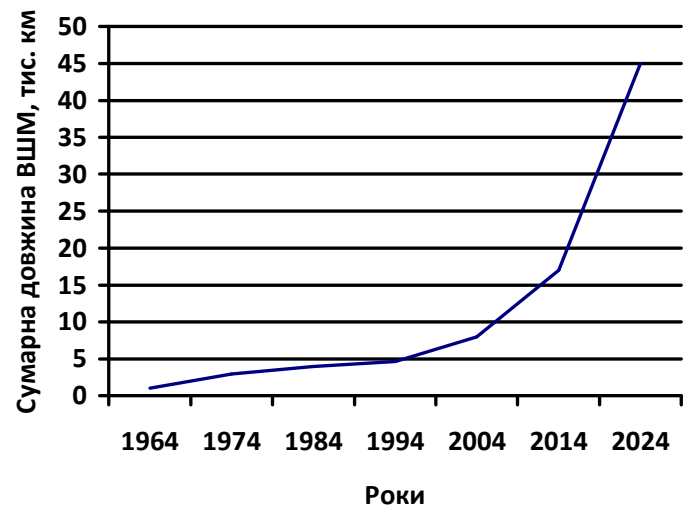

Рис. 2. Зростання протяжності ВШМ у світі (за даними МС3)

На даний момент протяжність високошвидкісних магістралей у Китаї більше 6 тис. км, в Японії - 2664 км, Іспанії - 2656 км, Франції - 2036 км, Німеччині 1334 км, Італії - 923 км. При цьому найбільший пасажирообіг спостерігається на ВШМ Японії, Франції та Німеччини.
У порівнянні із західноєвропейськими, українські залізниці характеризуються значно більшими обсягами перевізної роботи, високим рівнем інтенсивності руху, значно більшою вагою поїздів та осьових навантажень рухомого складу. На сьогодні резерви технічних можливостей залізничного транспорту, його провізної спроможності практично вичерпані. Виходячи 3 цього, питання впровадження швидкісного руху досі залишається складною проблемою та потребує кардинально нових рішень, цілого комплексу специфічних підходів та інноваційної системи управління.

В Україні і досі існує змішана система експлуатації залізничних ліній, тобто інфраструктура використовується як для пасажирського, так і для вантажного руху. Це створює значні обмеження щодо подальшого підвищення швидкостей руху, застосування прогресивного рухомого складу, підвищення комфорту пасажирів. За умов негативного впливу вантажних поїздів на стан залізничного полотна потребуються значні витрати на утримання його в належному стані. Для вирішення цієї проблеми доцільно розділити пасажирський та вантажний рух.

Протягом останнього десятиліття на залізницях України було проведено значний обсяг робіт 3 модернізації колійного розвитку, пристроїв автоматики, телемеханіки та зв'язку, розширено полігон 
обертання електропоїздів шляхом електрифікації ділянок, збільшено протяжність колії на залізобетонних шпалах, протяжність безстикової колії. Тобто було створено передумови для впровадження прискореного та швидкісного руху. Важливим поштовхом для створення мережі швидкісних перевезень стала реалізація проекту організації швидкісного транспортного забезпечення на час проведення чемпіонату Європи з футболу у 2012 році.

У 2004 році було розроблено та схвалено Кабінетом Міністрів України Концепцію державної цільової програми впровадження швидкісного руху пасажирських поїздів на 2005-2015 pp. Згідно з цією Концепцією було реалізовано комплекс робіт у Київському вузлі, здійснено поетапну реконструкцію головних залізничних колій на напрямках Київ - Харків, Полтава - Донецьк, Київ Львів. Для освоєння нового сегмента ринку - денних швидкісних перевезень відповідно до Наказу Міністерства інфраструктури України від 22 лютого 2012 р. №116 було засновано Державне підприємство «Українська залізнична швидкісна компанія» (ДП «УЗШК»). Основною діяльністю ДП «УЗШК» $\epsilon$ швидкісні пасажирські залізничні перевезення. Реалізація концепції дала змогу ввести в графік руху поїздів денні прискорені поїзди-експреси, скоротити час прямування між головними промисловими центрами України.

Адаптація рухомого складу до українських умов експлуатації, крім позитивних перетворень, все ж мала ряд труднощів. Зокрема було усунено невідповідності габаритів, пристосування до існуючої мережі електрифікації, а також досі потребує врегулювання питання невідповідності рухомого складу кліматичним умовам України [12]. Крім того, у лютому 2014 р. було виявлено тріщини в конструкції поїздів HYUNDAI, що поставило під загрозу життя пасажирів i змусило керівництво ДП «УЗШК» призупинити їх експлуатацію. Проведено необхідні випробування та готується модернізація цього рухомого складу, зокрема заміна всіх балок у рамках гарантійного обслуговування корейською компанією-виробником.

У майбутньому планується продовження реалізації задумів щодо впровадження високошвидкісного пасажирського руху на теренах залізниць України 3 можливістю досягнення на перспективу швидкостей руху до 350 км/год.

У процесі модернізації існуючої технічної системи руху швидкісних поїздів вирішуються задачі розрахунку параметрів і дослідження процесів у цій системі. При проведенні багатоваріантних розрахунків реальну систему заміняють моделлю [13].

У широкому розумінні модель визначають як відображення найбільш значущих властивостей об'єкта. Тобто математична модель технічного об'єкта - це сукупність математичних об'єктів i співвідношень між ними, яка адекватно відображає властивості досліджуваного об'єкта. Тому для існуючих залізничних колій при впровадженні на них швидкісного руху, з метою визначення доцільності реконструкції, вирішено побудувати імітаційну математичну модель.

Доцільність використання методу моделювання в питанні організації швидкісного пасажирського руху поїздів обумовлена необхідністю залучення великої кількості часу та фінансових витрат на безпосереднє дослідження системи експериментальними методами.

Для вирішення питань оптимізації швидкісного руху, що розглядаються в даній роботі, найбільш доцільним $\epsilon$ застосування апарата мереж Петрі. Це дасть змогу більш наочно подати систему організації швидкісного руху та отримати чітку інформацію щодо можливих варіантів функціонування системи. Для вирішення задачі встановлення, опису i наступного 
відтворення причинно-наслідкових зв'язків і взаємодії між елементами комплексу застосовують системи рівнобіжної обробки інформації і системи паралельно діючих об'єктів [14].

Мережі Петрі являють собою графічний i математичний засіб моделювання, що застосовується до різноманітних систем, у тому числі і до транспортних. Як графічний засіб мережі Петрі можуть використовуватися для наочного зображення системи, що моделюється, подібно до блок-схем, структурних схем і мережних графіків. Як математичний засіб аналітичне подання мережі Петрі дає змогу скласти рівняння стану, алгебраїчні рівняння й інші математичні співвідношення, які описують динаміку систем. На основі інформації, отриманої в результаті аналізу, можливе отримання оцінки не тільки модельованої системи, але і їі структури та поводження. Це перспективний інструмент опису i дослідження мультипрограмних, асинхронних, розподілених, паралельних, недетермінованих i (або) стохастичних систем обробки інформації [15].

Мережа Петрі являє собою деякий різновид орієнтованого графа із заданим початковим станом, що називається початковим маркуванням (чи розміткою) $M_{0}$. Граф $N$ мережі Петрі є орієнтованим зваженим дводольним графом і включає вузли (вершини) двох типів, що називають позиціями $P$ та переходами $T$, дуги в яких ведуть або 3 позиції в перехід, або 3 переходу в позицію. У графічному вигляді позиції зображуються кружками, а переходи - жирними рисками або прямокутниками. Дуги позначаються відповідною вагою (цілими числами), і дугу 3 вагою $k$ можна вважати еквівалентною $k$ рівнобіжним дугам. Маркування (стан) приписує кожній позиції ціле позитивне число $M(P)$, що дорівнює числу фішок у позиції $P$. Будь-яка позиція може мати або необмежену, або граничну місткість $K(P)$, що дорівнює максимально припустимому числу фішок у позиції $P$.

У задачах моделювання, де застосовуються поняття умов (станів) i подій, позиції відповідають умовам, а переходи - подіям. Кожен перехід (подія) позв'язаний з визначеним числом вхідних і вихідних позицій - аналогів відповідно до передумов та постумов цієї події. Наявність фішки в деякій позиції інтерпретується як істинність умови, що відповідає даній позиції, а також указує на наявність у позиції $k$ елементів чи даних відповідної кількості ресурсів.

Мережі Петрі поділяються на елементарні (наявність вхідного, вихідного місць і переходу між ними) і регулярні, що будуються за допомогою операцій 3 елементарними мережами. Так, регулярна мережа станції може бути приєднана до інших мереж (мереж перегонів та інших станцій), утворюючи при цьому нову мережу вузла.

Процес організації швидкісного залізничного руху покликаний зменшити загальні затрати часу на проходження маршрутів сполучення міст України. Максимальні швидкості руху поїздів категорії Інтерсіті+ обмежені технічними характеристиками рухомого складу, що експлуатується на сьогодні, та параметрами колійного розвитку. Тому ставиться задача не підвищення максимальних швидкостей руху, а оптимізації функціонування інфраструктури та скорочення часу прямування поїздів завдяки досягненню високих показників середньої маршрутної швидкості.

Позначимо пасажирську станцію початку маршруту $k$, тоді наступна станція буде $k+1$, при $k \in[1 ; K]$. Кожний поїзд, що пройде станції, позначимо i, при цьому $i \in[1 ; n]$.

Таким чином, цільова функція буде мати вигляд: 


$$
F(t)=\sum_{i=1}^{n}\left[t_{i}^{(k ; k+1)}+r_{i}^{k} \cdot t_{m p . c л}^{k}+q_{i}^{k} \cdot\left(\alpha^{k} \cdot t_{3 y n}^{(k ; i)}+t_{p . y .}^{(k ; i)}\right)\right] \rightarrow \min
$$

де $t_{i}^{(k ; k+1)}$ - час проходження i-м поїздом перегону від станції $\mathrm{k}$ до сусідньої станції $\mathrm{k}+1, \mathrm{xв}$;

$$
r_{i}^{k}=\left\{\begin{array}{l}
1, \text { якщо і - й поїзд пройде станцію k без зупинки, } \\
0, \text { якщо і - й поїзд зупиняється на станції k, } \\
0, \text { якщо станція к є початковою/ккінцево станцією } \\
\text { прямування поїзда; }
\end{array}\right.
$$

$t_{m p . c л}^{(k ; i)}-$ час проходження i-м поїздом станції k, при проходженні і-м поїздом станції k без зупинки (транзитом); хв;

$q_{i}^{k}=\left\{\begin{array}{l}1, \text { якщо і - й поїзд зупиняється на станції } \mathrm{k}, \\ 0, \text { якщо і - й поїзд пройде станцію } \mathrm{k} \text { без зупинки; }\end{array}\right.$

$\alpha^{k}=\left\{\begin{array}{l}1, \text { якщо станція } \mathrm{k} є \text { проміжною станцією } \\ \text { прямування поїзда }, \\ 0, \text { якщо станція } \mathrm{k} є \text { початковою /ккінцево станцією } \\ \text { прямування поїзда; }\end{array}\right.$

$t_{3 y n}^{(k ; i) /}$ - тривалість стоянки і-го поїзда на к-й станції, хв;

$t_{p . y .}^{(k ; i) /}-$ час на розгін/уповільнення i-го поїзда при наявності зупинки на станції $\mathrm{k}, \mathrm{xв.}$

На лінії Київ - Полтава - Харків здійснюється рух як швидкісних, так i звичайних пасажирських та вантажних поїздів. При цьому доводиться стикатися 3 численними обмеженнями швидкості, викликаними наявністю кривих, штучних споруд, стрілочних переводів, що потребують зменшення швидкості. Реконструкція лінії дасть змогу зменшити кількість таких ділянок та збільшити середню дільничну швидкість поїздів Інтерсіті+. Необхідно мінімізувати час проходження станцій та перегонів швидкісними поїздами. Для вирішення цієї задачі побудуємо модель руху поїздів за допомогою мереж Петрі.

У поставлених задачах моделювання використовуються поняття умов та подій, умови позначаються позиціями $\left(\mathrm{p}_{\mathrm{i}}\right)$, а події - переходами $\left(\mathrm{t}_{\mathrm{i}}\right)$.
Модель прямування швидкісних поїздів станціями та перегонами показано на рис. 3. У нашому випадку фішкою буде поїзд. Позиції $\mathrm{P}_{\mathrm{i}}$ відображають стан (умови прямування) поїзда в результаті спрацювання переходів.

Побудуємо модель для дослідження процесу проходження ділянки Огульці Совнаркомівська. У нинішніх умовах на даній ділянці діють такі обмеження швидкості:

- станція Огульці (39 км) - 120 км/год;

- перегін між станціями: до 35 км 160 км/год, 37,9 - 38,4 км - крива 1 140 км/год, 35,5 - 45,5 км - крива 2 100 км/год;

- станція Совнаркомівська - 60 км/год.

Поїзд проходить дану ділянку більш ніж за 5 хв. Модель на даній ділянці буде мати вигляд, наведений на рис. 3. 


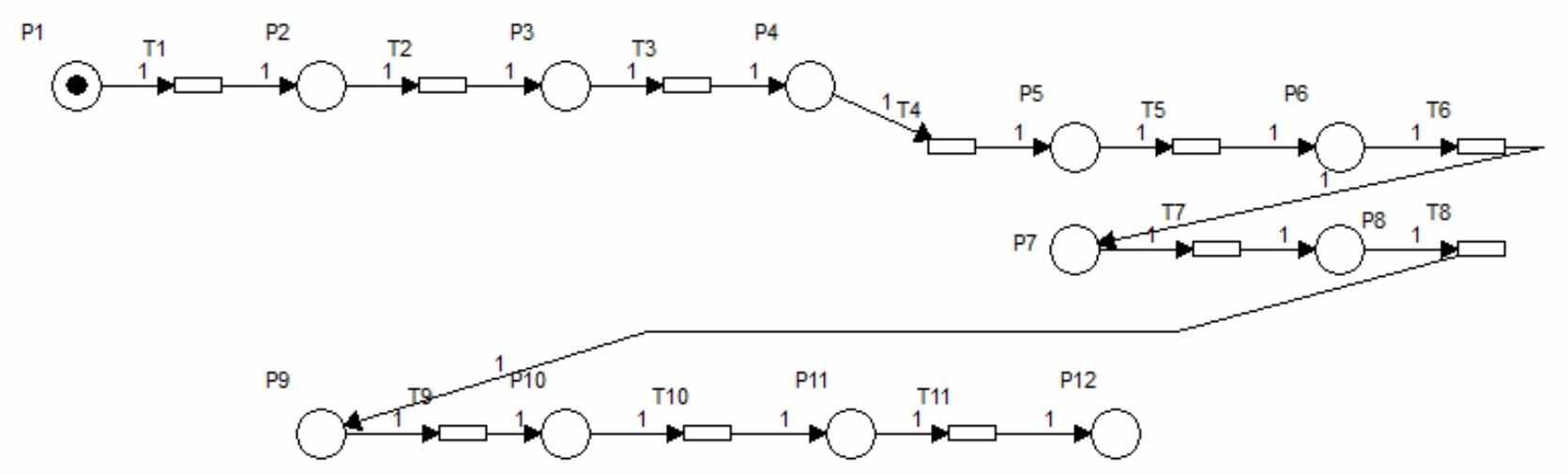

Рис. 3. Модель проходження швидкісним поїздом ділянки Огульці - Совнаркомівська

У даній моделі під позиціями та переходами позначені: $\mathrm{P}_{1}-$ готовність поїзда до проходження станції Огульці; $\mathrm{P}_{2}$ - наявність стрілочних переводів, що потребують зменшення швидкості; $\mathrm{P}_{3}$ готовність до проходження стрілочних переводів на станції; $\mathrm{P}_{4}$ - готовність до проходження перегону; $\mathrm{P}_{5}-$ наявність кривої 1, що потребує зменшення швидкості; $\mathrm{P}_{6}$ - готовність до проходження кривої $1 ; \mathrm{P}_{7}$ - наявність кривої 2 , що потребує зменшення швидкості; $\mathrm{P}_{8}-$ готовність до проходження кривої $2 ; \mathrm{P}_{9}-$ готовність поїзда до проходження станції Совнаркомівська; $\mathrm{P}_{10} \quad-\quad$ наявність стрілочних переводів, що потребують зменшення швидкості; $\mathrm{P}_{11}$ - готовність до проходження стрілочних переводів на станції; $\mathrm{P}_{12}$ - готовність до проходження перегону; $\mathrm{T}_{1}-$ проходження ділянки наближення до станції Огульці; $\mathrm{T}_{2}$ зниження швидкості; $\mathrm{T}_{3}-$ проходження стрілочних горловин станції Огульці зі зменшеною швидкістю; $\mathrm{T}_{4}-$ проходження ділянок віддалення станції; $\mathrm{T}_{5}-$ зниження швидкості; $\mathrm{T}_{6}$ - проходження кривої 1 зі зниженою швидкістю; $\mathrm{T}_{7}-$ зниження швидкості; $\mathrm{T}_{8}$ - проходження кривої 2 зі зниженою швидкістю; $\mathrm{T}_{9}-$ проходження ділянки наближення до станції Совнаркомівська; $\mathrm{T}_{10} \quad-$ зниження швидкості; $\mathrm{T}_{11}$ - проходження стрілочних горловин станції Совнаркомівська зі зменшеною швидкістю.
У результаті отримуємо: фішка проходить станції та перегон між ними за час $\mathrm{T}=16$ (рис. 4). Час переходу фішки $\mathrm{T}=1$ у моделі еквівалентний часу прямування поїзда $\mathrm{t}=20$ с. Тобто поїзд проходить $\mathrm{t}=320 \mathrm{c}=5$ хв $20 \mathrm{c}$.

Після проведення реконструкції та зняття швидкісних обмежень (приведення ix до 140 км/год) модель матиме значно спрощений вигляд (рис. 5).

Позиціями й переходами позначені: $\mathrm{P}_{1}$ - готовність поїзда до проходження станції Огульці; $\mathrm{P}_{2}$ - відсутність швидкісних обмежень при прямуванні станцією Огульці; $\mathrm{P}_{3}$ - готовність до проходження перегону; $\mathrm{P}_{4}$ - відсутність швидкісних обмежень на перегоні; $\mathrm{P}_{5}$ - готовність поїзда до проходження станції Совнаркомівська; $\mathrm{P}_{6} \quad$ - відсутність швидкісних обмежень при прямуванні станцією Совнаркомівська; $\mathrm{P}_{7}$ - готовність до проходження перегону; $\mathrm{T}_{1}-$ проходження ділянки наближення до станції Огульці; $\mathrm{T}_{2}$ - проходження станції Огульці без зменшення швидкості; $\mathrm{T}_{3}-$ проходження ділянок віддалення станції; $\mathrm{T}_{4}-$ проходження перегону без зменшення швидкості; $\mathrm{T}_{5}$ - проходження ділянки наближення до станції Совнаркомівська; $\mathrm{T}_{6}$ - проходження станції Совнаркомівська без зменшення швидкості.

У результаті фішка (поїзд) буде проходити станції та перегін між ними за час $\mathrm{T}=8$ (рис. 6), тобто за $\mathrm{t}=160 \mathrm{c}=2$ хв $40 \mathrm{c}$. 


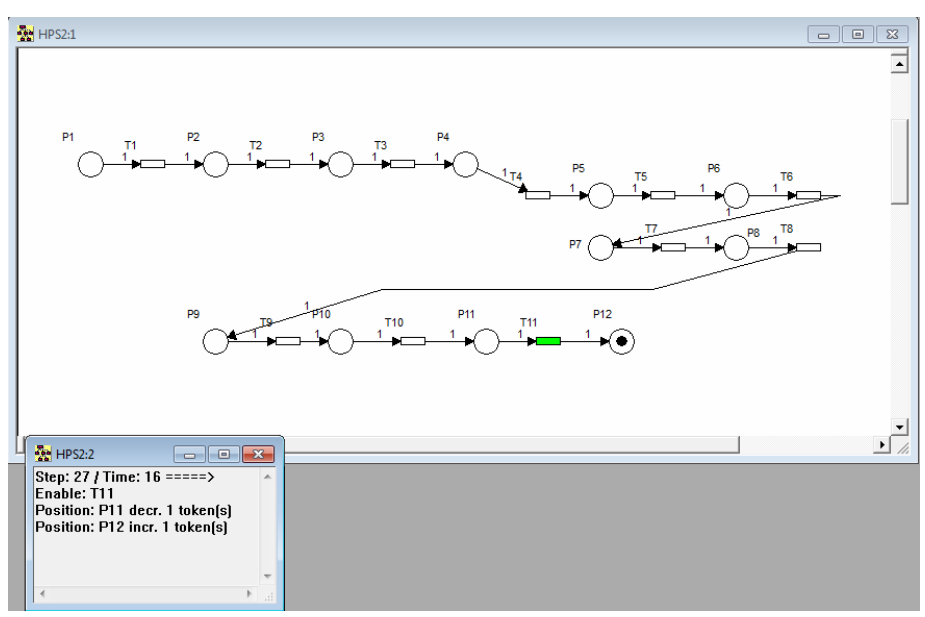

Рис. 4. Результати моделювання проходження ділянки Огульці - Совнаркомівська до реконструкції

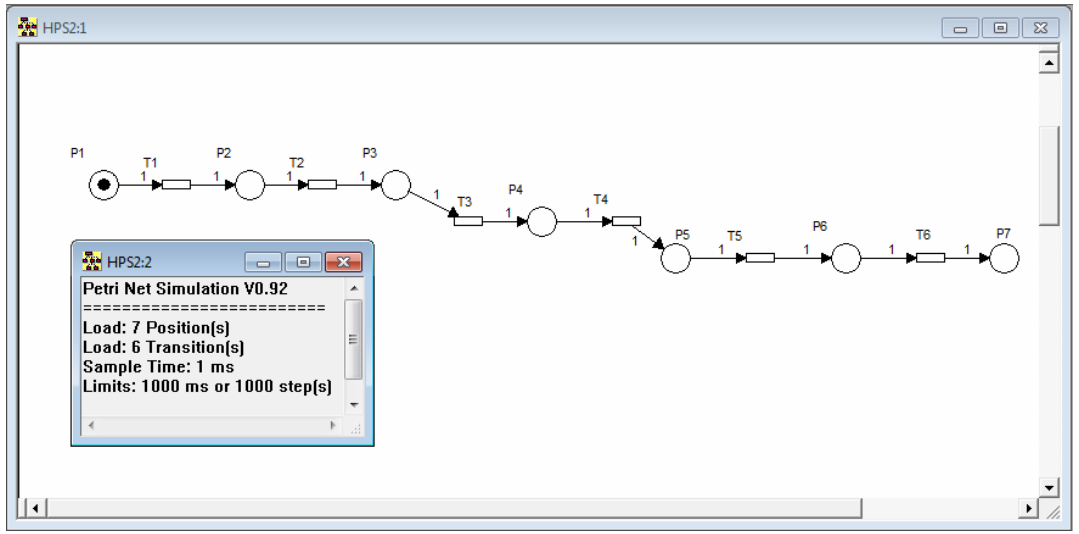

Рис. 5. Модель проходження швидкісним поїздом ділянки Огульці - Совнаркомівська після проведення реконструкції

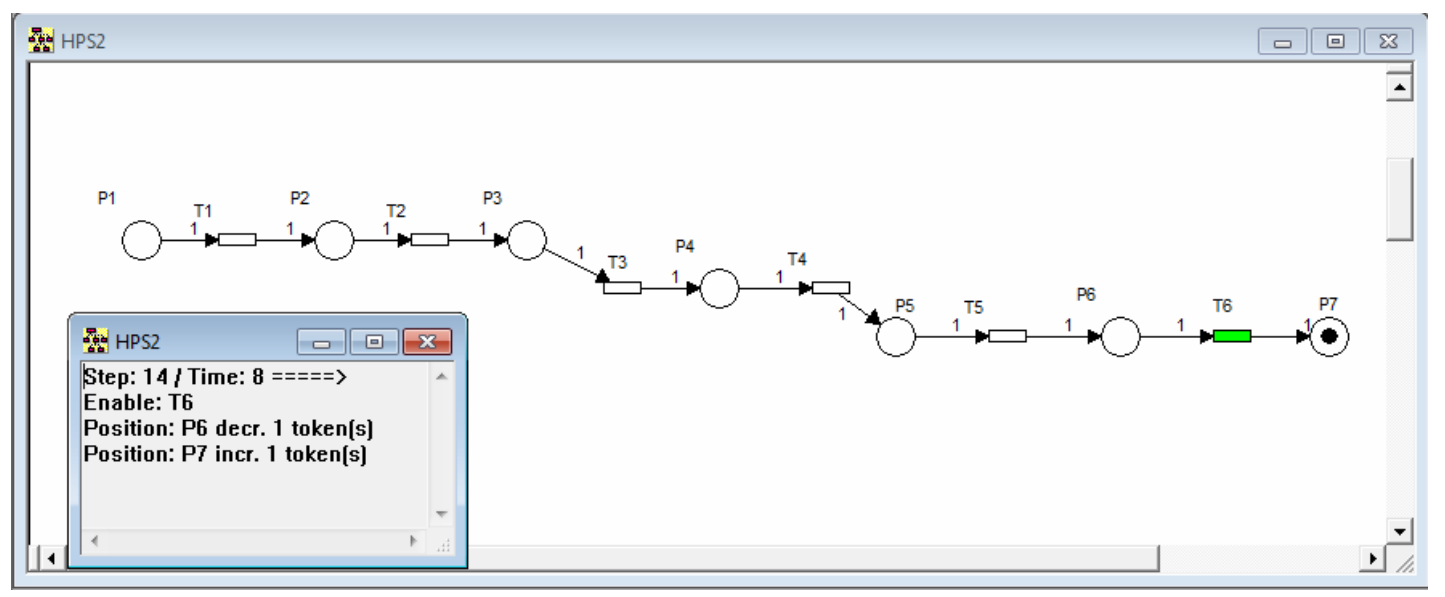

Рис. 6. Результати моделювання проходження швидкісним поїздом ділянки Огульці - Совнаркомівська після реконструкції 
Таким чином, використання розробленої моделі дає змогу оцінити часові переваги ще до проведення будьяких робіт на ділянці i визначити їх майбутню ефективність.

Висновки 3 дослідження i перспективи, подальший розвиток у даному напрямку. На підставі виконаного аналізу розвитку систем сучасного високошвидкісного залізничного транспорту, технічних і технологічних рішень, світового досвіду організації швидкісних пасажирських перевезень можна говорити про гостру необхідність удосконалення існуючої залізничної інфраструктури України та скорочення відставання в умовах стрімкого зростання швидкостей руху.

Впровадження швидкісного залізничного руху надасть можливість Україні досягти значних позитивних зрушень як в економічному, так i в соціальному плані. Враховуючи довгостроковість виконання подібних проектів та масштабність потрібних інвестицій, можна 3 упевненістю говорити про необхідність детального розгляду всіх можливих варіантів реалізації поставленої мети і техніко-економічного обгрунтування вибору оптимального шляху. Саме розроблення політики розвитку на початковому етапі $є$ вирішальним фактором подальшого успіху. Тому для розроблення програми інтеграції швидкісного руху в транспортний комплекс України необхідно:

- створити потужну базу інфраструктури, що відповідала б світовим стандартам та забезпечувала надійний i безперебійний швидкісний рух;

- визначити найбільш перспективні та економічно вигідні напрямки, розробити мережу швидкісного руху, яка забезпечить доступність для пасажирів та поєднає основні промислові та культурні центри України;

- визначити найприйнятніший варіант рухомого складу із запропонованих світовими виробниками;

- розробити основні технічні, технологічні, організаційні, економічні, правові та екологічні аспекти роботи ВШМ;

- розробити методи та модель розподілу пасажиропотоків при застосуванні швидкісного руху.

Створення високошвидкісної мережі 3 великою пропускною спроможністю, яка б відповідала світовим та європейським стандартам зокрема, - ось найкращий спосіб підвищення рейтингу залізниць серед інших видів транспорту. Тому необхідною $\epsilon$ взаємодія та міжнародний обмін досвідом реалізації таких проектів. Подальше інтегрування українських залізниць в європейську високошвидкісну мережу відкриє нові, значно ширші можливості та перспективи.

\section{Список використаних джерел}

1. Альошинський, Є. С. Аналіз можливості організації місцевої роботи на залізничних станціях в умовах впровадження швидкісного пасажирського руху [Текст] / Є. С. Альошинський, О. С. Губачова, С. О. Світлична, Г. О. Сіваконева, Т. О. Ланчак // Східно-Європейський журнал передових технологій. - Харків, 2012. - Т. 2. - №3(56). - С. 42-46.

2. Альошинський, Є. С. Організація вантажного руху на станції Лозова Південної залізниці в умовах впровадження швидкісного руху [Текст] / Є.С. Альошинський, О. С. Губачова, С. О. Світлична, Г. О. Сіваконева // Інформаційно-керуючі системи на залізничному транспорті. - Харків: УкрДАЗТ, 2013. - №3(100). - С. 54-59.

3. Сіваконева, Г. О. Удосконалення технології пасажирських залізничних перевезень у безпересадковому сполученні [Текст]: дис... канд. техн. наук 05.22.01 - транспортні системи / Г. О. Сіваконева. - Харків: УкрДУЗТ, 2015. - 256 с.

4. Примаченко, Г. О. Дослідження сучасного стану системи пасажирських залізничних перевезень в Україні [Текст] / Г. О. Примаченко // Тези Х Ювілейної міжнародної науково- 
практичної конференції «Проблеми економіки та управління на залізничному транспорті ЕКУЗТ 2015» (30 червня - 1 липня 2015 р., м. Одеса (ДЕТУТ)). - К.: ДЕТУТ, 2015. - С. 124-125.

5. Примаченко, Г. О. Розробка пропозицій щодо підвищення доходності пасажирських залізничних перевезень в Україні [Текст] / Г. О. Примаченко // Східно-Свропейський журнал передових технологій. - Харків, 2015. - №6/3(78). - С. 33-39.

6. Сіваконева, Г. О. Розвиток швидкісного руху на залізничному транспорті в Україні [Текст] / Г. О. Сіваконева // Сб. науч. тр. SWorld по материалам междунар. науч.-практ. конф. «Современные направления теоретических и прикладных исследований'2011» (20-31 марта 2012 г., г. Одесса). - Одесса, 2011. - Т. 2. - С. 42-44.

7. Акуленко, А. С. Перспективи розвитку залізничних перевезень у сполученні СвропаАзія на території України [Текст] / А. С. Акуленко // Бюл. ОСЗ. - К., 1997. - № 6. - С. 3-6.

8. Алейник, В. С. Будівництво та реконструкція транспортної мережі України для збільшення пропускної спроможності та запровадження швидкісного руху поїздів [Текст] / В. С. Алейник, В. В. Козак та ін. // Залізничний транспорт України. - К., 2010. - №5. - С. 3-6.

9. Анисимов, П. С Вопросы организации высокоскоростного движения [Текст] / П. С. Анисимов // Железнодорожный транспорт. - М., 2010. - №6. - С. 73-77.

10. Грищенко, Н. В. Напрямки реформування та державне регулювання розвитку залізничного транспорту України [Текст] / Н. В. Грищенко // Залізничний транспорт України. - К., 2010. - №2. - С. 10-12.

11. Лючков, Д. С. Високошвидкісний рух6 світовий досвід та перспективи України [Текст] / Д. С. Лючков, В. О. Патриченко // Східно-Свропейський журнал передових технологій. - Харків, 2013. - № 11(45). - С. 14-19.

12. Альошинський, Є. С. Впровадження швидкісного руху пасажирських поїздів на дільниці Гребінка - Полтава - Красноград - Харків - Лозова. Станція стикування постійного $3,3 \kappa \mathrm{B}$ та змінного 27,5кВ видів тягового струму по ст. Лозова. Розробка технології обслуговування під'їзних i тракційних колій залізничних та промислових підприємств Лозовського вузла [Текст] / Є. С. Альошинський, О. М. Огар, М. Ю. Куценко, Г. О. Сіваконева, О. С. Губачова, С. О. Світлична // Звіт про НДР ДР 0112U000423. - Харків: УкрДАЗТ, 2012. - 362 с.

13. Советов, Б. Я. Моделирование систем [Текст]: учеб. для вузов / Б. Я. Советов, С. А. Яковлев. - 3-е изд., перераб. и доп. - М.: Высш. шк., 2001. - 343 с.

14. Мурашко, А. Г. Первое знакомство с сетями Петри [Текст] / А. Г. Мурашко // Учебное пособие. - К.: УМК ВО, 1988. - 71 с.

15. Сіваконева, Г. О. Побудова математичних моделей технологічних ліній обробки пасажирських поїздів на залізничних станціях [Текст] / Г.О. Сіваконева // Зб. наук. праць УкрДАЗТ. - Харків: УкрДАЗТ, 2012. - Вип. 131. - С. 61-67.

Рецензент д-р техн. наук, професор Є.С. Альошинський

Примаченко Ганна Олександрівна, кандидат технічних наук, асистент, кафедра транспортних систем та логістики, Український державний університет залізничного транспорту (УкрДУЗТ).

Тел.: 057-730-19-55. E-mail: AnnaPrimachenko@i.ua.

Аскеров Зульфугар Аскер Огли, магістрант кафедри транспортних систем та логістики, Інститут перепідготовки та підвищення кваліфікації кадрів Українського державного університету

залізничного транспорту (ІППК УкрДУЗТ). Тел.: 057-730-19-55.

Prymachenko Ganna Oleksandrivna, Ph.D., assistant, The Department of Transport Systems and Logistics, Ukrainian State University of Railway Transport (UkrSURT). Ph.: 057-730-19-55. E-mail: AnnaPrimachenko@i.ua. Askerov Z. A., Undergraduate of transport systems and logistics, Institute of retraining and advanced training of Ukrainian State University of Railway Transport (IRAT UkrSURT). Ph.: 057-730-19-55.

Стаття прийнята 18.04.2016 p. 